\title{
The environmental impact assessment (EIA) process management in shale gas projects
}

\begin{abstract}
Taking action related with the extraction of natural gas from shale deposits, will require associating different approaches and methods in the field of strategic planning and management with elements of environmental management and decision making processes, using environmental impact assessments. The article presents selected conditions, including those arising from EU, national and regional strategies and policies, which must be taken into account in the implementation of projects related to shale gas.
\end{abstract}

Key words: shale gas, strategic environmental assessment, environmental impact assessment of projects.

\section{Zarządzanie procesem oceny oddziaływania na środowisko w projektach inwestycyjnych związanych z wydobywaniem gazu ze złóż łupkowych}

Podjęcie działań związanych z przyszłym zagospodarowaniem gazu ziemnego ze złóż łupkowych wymagać będzie kojarzenia różnych podejść i metod z zakresu planowania i zarządzania strategicznego z elementami zarządzania środowiskiem oraz procesami podejmowania decyzji z wykorzystaniem ocen oddziaływania na środowisko. W artykule zaprezentowano wybrane uwarunkowania, w tym wynikające z unijnych, krajowych oraz regionalnych strategii i polityk, które muszą być brane pod uwagę przy realizacji projektów związanych z gazem z formacji łupkowch.

Słowa kluczowe: gaz z formacji łupkowych, strategiczna ocena oddziaływania na środowisko, ocena oddziaływania przedsięwzięcia na środowisko.

\section{Introduction}

Currently, it is estimated that domestic natural gas resources in unconventional deposits are larger than the proven reserves of conventional deposits [4]. Natural gas from unconventional deposits could, in the future, provide a new perspective for the country's energy balance. The shale gas occurring in shale rocks, characterized by low permeability, dominates unconventional natural gas resources. Tight gas deposits, trapped in the pores of sandstone and carbonate rocks, with very low permeability, are also rich [3]. The presence of natural gas in rocks with low permeability requires varying methods of extraction, i.e. more complex and technically advanced methods, making the operation more complex and more costly, as compared with the extraction of natural gas from conventional fields $[1,2]$. The current state of the advancement of exploration and research work concerning gas deposits in shale rocks does not yet enable cost-effective extraction. It is necessary to conduct intensive research to make the technology of its extraction more suitable for the Polish mining geological conditions, particularly the hydraulic fracturing technology, as well as to solve other problems, including the issue of the socio-economic factors associated with the development of such deposits.

Despite pessimistic forecasts about the possibility of the economic use of natural gas from unconventional deposits, 
the draft Polish Energy Policy until 2050 envisages promoting the activities of investors related to exploration and exploitation of unconventional resources (shale gas, tight gas and coal-bed methane) [15]. Taking into account the forecasted conditions and directions of the country's development, the draft energy policy includes alternative scenarios, adopted for further analysis, including the scenario of a combined share of natural gas and renewable sources in the energy balance of approx. $50 \div 55 \%$. Other scenarios are also characterized by moderate growth of the role of natural gas. This determines the approach to the debate on effective and efficient management of projects relating to the exploitation of shale gas.
Gas extraction, as in the case of other investment projects of this scale, will include the following consecutive phases: pre-investment, investment and operations. These phases will encompass various actions taken in parallel or creating a sequence of repetitive executive actions.

Effective management of any investment project related to the extraction of shale gas requires the identification of the key environmental determinants at individual stages: programming (investment strategies), planning and location of project, design, implementation, exploitation (including the intensification of exploitation), end of the extraction (mining plant decommissioning) and reclamation.

\section{Development policy}

From the early stages of the preparation of any investment related to the extraction of shale gas, it will be necessary to take into account the implemented EU, national and regional policies - in accordance with the requirements of sustainable development and the principles of environmental policy, providing a framework for land-use planning, environmental resources management, environmental protection and others.

Focusing on the efficient use of energy resources in the development process is both an opportunity and a necessity in the European Union. Due to the more efficient use of resources, including those connected with energy - the EU is hoping to achieve many goals. This should specifically be the key condition for the progress in efforts to combat climate changes, including further reduction of greenhouse gas emissions. It is also important for the protection of ecological resources and energy resources that will guarantee, the quality of life for present and future generations.

An expression of this vision is the document Europe 2020 - A strategy for the promotion of smart and sustainable development conducive to social inclusion, which aims at creating a strategic framework for supporting change leading to a gradual transition to a low-emission economy based on efficient use of resources.

The national strategic documents which focus on the key activities supporting development in the long and medium- term horizons, are also in line with the Europe 2020 Strategy and highlight the socio-economic, spatial and regional problems. These include, among others:

- Long-term National Development Strategy. Poland 2030 defines the main directions of the economic and social development [10],

- Medium-term National Development Strategy 2020 stressing the quality improvement of the environment in connection with the need to ensure energy efficiency and diversification of fuels and energy supplies [17],

- The National Strategy of Regional Development 2010 2020: Regions, Cities, Rural Areas - with its emphasis on "the effective utilization of specific regional and other territorial development potentials for the development of the objectives of the country" [14],

- The Strategy for Energy Security and the Environment2020 prospect. - Integrating the environmental policy with the energy policy. The development opportunities in it, include, among others: "potentially large shale gas resources". It attaches key importance to the continuation of knowledge concerning energy resources and to identifying deposits of strategic importance. With respect to shale gas, it involves the preparation and implementation of a transparent legal and regulatory structure in the area of its exploitation [16].

\section{Environmental policy}

The EU Environmental Policy, and more specifically, the policy relating to the environment, defines the ecological objectives to be implemented, referring to the widely-understood environmental aspects of the management process, as well as to the category of sustainable development. Long-term programs are important to achieve the environmental objectives (e.g. the $6^{\text {th }} / 7^{\text {th }}$ Framework Program of Action for the Environment).
They determine the directions, goals, priorities and form the basis for the environmental policy in a certain time perspective in all European Union countries. They constitute legally binding instruments but they are often the basis for issuing secondary legislation of a binding nature.

The most commonly used instruments of the EU law in the field of environment protection are directives and decisions 
that are binding acts. They usually relate to a broad spectrum of content and issues relating to shale gas are not singled out as separate. The aim of the directives is primarily to establish environmental standards and to harmonize national systems in this area. The activities associated with obtaining shale gas, ranging from planning to ceasing of operations, are subject to both general Union rules as well as specific acts of the EU legislation on environmental protection. Among the many, the following should be mentioned:

\section{- Directive 2014/52/EU of the European Parliament and} of the Council amending Directive 2011/92/EU on the assessment of the effect of certain public and private projects on the environment (i.e. the Assessment Directive) [12],

- Directive 94/22/EC of the European Parliament and of the Council of 30 May 1994 on the conditions for granting and using authorizations for the prospection, exploration and production of hydrocarbons (i.e. the hydrocarbon directive) [13].

At the EU level, there are also other documents which are not legally binding, such as recommendations and opinions, resolutions, announcements and the above-mentioned action programs, as well as so-called environmental agreements. They define the objectives or directions of actions that, in the shortor long-term perspective, may be reflected in normative acts.

The issues related strictly to the issues of sourcing natural gas from shale deposits are referred to in the European Commission Recommendation of 22 January 2014 on the basic principles of exploration and exploitation of hydrocarbons (such as shale gas) using intensive hydraulic fracturing [19]. The Commission Recommendation is accompanied by a Communication from the Commission of the European Parliament and the Council on the identification and exploitation of hydrocarbons (such as shale gas) in the EU using intensive hydraulic fracturing, which examined the opportunities and challenges associated with the use of fracturing, to extract hydrocarbons. Both documents (the Recommendation and the Communication) are part of a wider initiative of the European Commission whose aim is to introduce an integrated policy framework on climate and energy up to 2030.

The preamble to the Recommendation of the European Commission emphasized, that all the general provisions of Community, including the environmental ones, apply to all activities in the field of identification and production of hydrocarbons, including actions involving conducting intensive hydraulic fracturing on a large scale. It also notes that the current EU legislation includes imperfections, that result from the fact, that the provisions were compiled when intensive hydraulic fracturing was not used in Europe. This applies, in particular, to strategic planning, assessment of the risks of groundwater, the integrity of wells, baseline and operational monitoring, methane capture and the disclosure of information on chemicals used in individual wells. The Recommendation states: "Upgrading this recommendation or the development of legal binding provisions may be necessary in the light of technological progress, the need for mitigating the risks and effects of exploration and exploitation of hydrocarbons using techniques other than intensive hydraulic fracturing, unforeseen problems ...".

The main objective of the environmental policy of a country is the assurance of the ecological safety of the country (population, social infrastructure and natural resources), through the implementation of sustainable development, which aims at effective regulation and controlling the use of the environment, so as not to endanger the quality and the sustainability of natural resources [6]. The components of the national ecological policy are detailed policies, including: the nature conservation policy and the preservation of biodiversity, the environmental policy, the policy of the use of the environmental resources and advantages and the policy of shaping ecosystems and landscapes.

The principles of environmental protection, thus the assumption of the National Environmental Policy, must take account of the policies, strategies, plans and programs established at the national level, in particular, such areas as industry, energy, water management, waste management and others. Under the current law, these documents require carrying out a strategic environmental assessment.

According to the Recommendation of 22 January 2014, the European Commission encourages Member States to carry out a strategic environmental impact assessment before granting licenses for the exploration or extraction of shale gas. The assessment should be carried out on the basis of the requirements (relating to plans, programs and strategies) of Directive 2001/42/EC [11]. It should therefore apply to a nationwide program to acquire natural shale gas, if such would be developed in the country.

\section{Environmental management}

Environmental management in the preparation and implementation of extracting gas from shale deposits will rely on the management of the complex processes of the use, protection and development of the environment - as required by the law and the findings of current and future strategic documents. It will be necessary to associate various approaches and methods within strategic planning and management with the elements of environmental management and decision-making processes. 
The pre-investment phase will include various activities undertaken in parallel and some of them will proceed to the next phase - the investment phase, consisting of repetitive sequences of executive actions, resulting in gas exploitation carried out together with the intensification of its exploitation in order to extend the exploitation time of the given deposit, until shutting down individual installations, decommissioning and reclamation.

Successful management of the operation of shale gas requires the identification of various kinds of environmental conditions associated with subsequent actions at different stages, involving:

- development of investment strategies, taking into account external conditions of the analysis of the options and supporting research and studies,

- development of principles and concepts of operation, together with a feasibility study,

- planning and location of the project, specifying the spatial and environmental determinants of its implementation,

- technical and technological design,

- implementation of the investment process,

- start-up of gas exploitation and operation of the mine plant,

- intensification of exploration to extend the exploitation of the deposit (fracturing, drilling new wells) and subsequent liquidation of exploited holes,

- end of the operations and mining plant decommissioning,

- land reclamation after mining plant decommissioning.

The relationship of individual actions related to specific procedures and administrative decisions required, as part of sequentially successive stages, will create a complex grid of connections and interdependences. Identifying the core relations between the activities of successive stages (programming, planning, locating and designing investment), associated with the extraction of shale gas, will be crucial for the effectiveness and efficiency of investments.

In the pre-investment phase, there will be a need for the Concessionaire to take into account the national strategic documents concerning the development policy, the environmental policy, etc., as well as the provisions of the European Commission Recommendation of 22 January 2014, not included in the national regulations. The material terms and conditions of this recommendation, should be seen in relation to the sequence of activities related to the preparation and exploitation of shale gas in the next stages [9].

Subsequent stages, from programming activities, through planning and locating investments and the environmental impact assessment, will assure specific conditions and requirements relating to the preparation of the investment, its operation and the end of exploitation as well as the mining plant land reclamation. The significant findings of the programming stage of gas extraction should be reflected in the basic regional documents in the areas of strategy development and planning and should be subject to the processes of strategic environmental assessment.

Planning and locating the mining operations will require updates of planning documents - the study of conditions and directions of spatial development and the proper use of the local development plan. Both planning procedures will be accompanied by assessments using the forecasted draft study / planned impact on the environment.

The next step will be to obtain a decision on the environmental conditions of the project on the basis of a report on the impact of the proposed project on the environment, among others, using its geological-investment documentation.

The design stage in the proceedings for obtaining the building permit may require carrying out procedures for reassessment of the environmental impact.

The start of shale gas extraction is a decision of strategic importance, to be taken by the Concessionaire after analyzing the results of exploration works, studying other geological and mining data, analyzing legal and formal issues, the environmental and spatial conditions, the study of financial and economic aspects of the investment. The complex process of preparing such a serious investment undertaking, requires associating various mutually interdependent aspects in a multistage process of the preparation of the investment. The main problem areas will include:

- program-interdependence issues of policy development of the country and the region, created at the government level and the provincial government,

- issues of planning and localization, correlated with the findings of the sub-regional, regional and local instruments adopted, with the participation of representatives of the administration and local governments at various levels and local communities,

- environmental issues, primarily related to the results of strategic environmental assessments and impact assessments for the projects implemented and involving the authorities of government administration, ecological organizations and the public,

- geological and mining issues and those implemented with the participation of public authorities, geological administration, designers and experts, and

- design, technical and technological issues carried out with the authorities, designers and experts.

The procedures for environmental impact assessments of individual investment projects will be the most socialized, generally transparent and conducted with the participation of interested entities. 


\section{Managing the process of EIA}

The environmental legislation, including Directive 2014/52/EU, amending Directive 2011/92/EU, on the assessment of the effects of certain public and private projects on the environment [12] as well as the recommendations contained in the Recommendation of the European Commission, on the basic principles of the identification and extraction of hydrocarbons with the use of intensive hydraulic fracturing, show the need for an integral and sequential approach to the management of the assessment of any impact on the environment in the preparation, implementation and operation of shale gas exploitation from deposits. The multiphase process of Environmental Impact Assessment (EIA), should become the main theme of integration activities in these problem areas and subsequent stages of the investment related to gas exploitation. The results of the subsequent procedures will create conditions for further procedures in the EIA process.

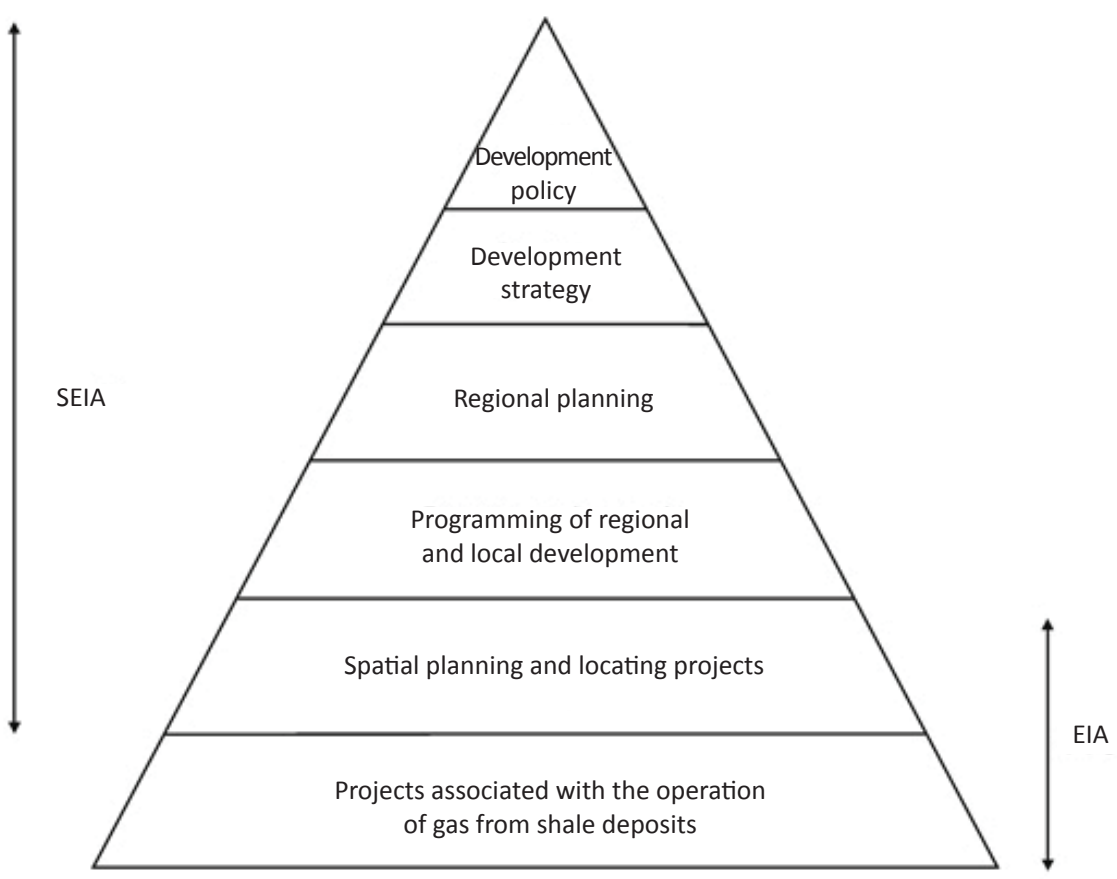

Fig. 1. Interdependence of the programming and planning the development and extraction of shale gas with the process of environmental impact assessment

(own development): SEIA - strategic environmental impact assessment, EIA - environmental impact assessment for the investment affect the quality of the implementation phase of a specific project, including lowering the "level of conflict".

The hierarchy of environmental impacts is important for the variant analysis of the system of impact assessments. Relationships between the hierarchical system of documents and the planned projects and the hierarchy of environmental assessments is illustrated in Figure 1. In general, the hierarchy consists of: a policy - a strategy - a plan - a program - a planned project. These documents are related to the environmental impact assessment of the projects of the listed documents (i.e. the so-called strategic assessments - SEIA) and the Environmental Impact Assessment of the planned investment projects (i.e. the so-called project assessment - EIA).

The advantage of the hierarchical system of the relationships of strategic documents and the related system of environmental impact assessment is the ability to analyze relevant environmental relationships at the right time. This is illustrated in Figure 2.

Solving environmental protection problems. Environmental protection problems, due to the number of interested entities, the general public access to environmental information and the possible broad public participation, including the representatives of environmental organizations, will require multilateral coordination already at the early stage of the preparations of gas extraction. The coordination will involve many different aspects, such as: assessment of the legislation and executive regulations, the scope of research and environmental monitoring, decision-making processes, decisions and procedures to obtain environmental permits, implementation of environmental monitoring, analyzing and reducing risks associated with environmental protection.

The process of environmental impact assessment should take into account not only the preparation, operation and de-

The essence of the procedures of environmental impact assessment is to identify the different variants of achieving the objective pursued and to compare their effects, primarily including the environmental ones. The variant analysis, being a mandatory part of the procedure of the environmental impact assessment, largely contributes to identifying the forecasted problems, enabling their mitigation or elimination. Thus, they commissioning of the mining plant but also such issues as the development of accompanying gas infrastructure, location of backup facilities and other facilities or the transformation of the infrastructure conditioning the extraction of shale gas.

The process of Environmental Impact Assessment are concluded with a post-implementation analysis [5]. It is a report that compares the actual impact of the investment 


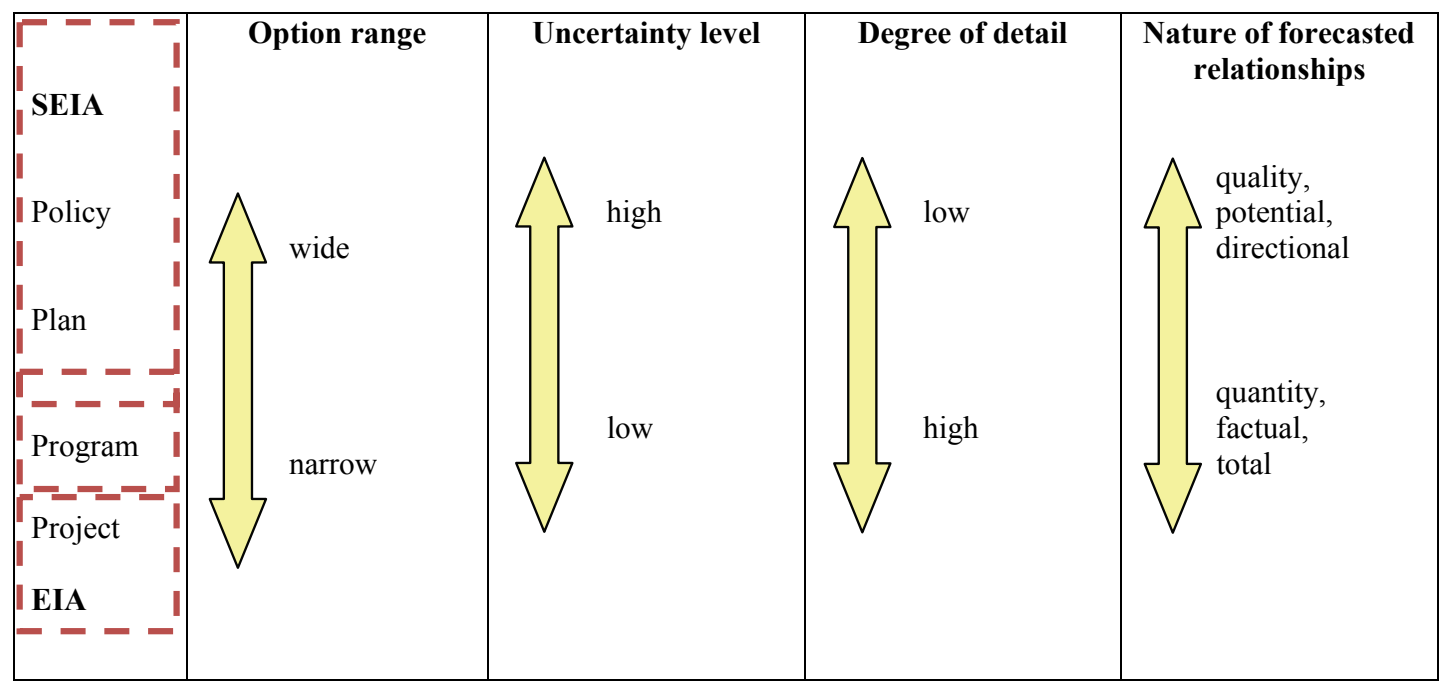

Fig. 2. The nature and scope of the analyzes carried out within environmental impact assessments (according to [8])

process and the operational phase of the installation with the ones forecasted in the pre-investment phase and the conditions contained in the decisions allowing for the investment. Subject to the current law (i.e. the EIA Act [18]), such an obligation can be imposed by an authority in any environmental decision, taken after the assessment of the environmental impact.

Environmental monitoring program. Preparation of reports on the environmental impact, will provide initial information on the state of the environment and the processes occurring in it. This information, along with data on the technology used, substances, processes and permitting conditions enable the development of the environment monitoring program. This program is based on the conclusions of the environmental studies, and the EIA reports shall provide control over the impacts on all of the stages of the implementation and functioning of the mining plant exploiting shale gas.

Environmental protection management plan. One of the main objectives of this plan is a timely response to the uncertainties identified at the stage of the EIA report. There may be various kinds of remedial actions taken to mitigate or limit the negative impacts. These include: actions taken to reduce the risks associated with the implementation of the project and its individual stages [7]. In specific environmental situations, there may be need to develop and implement compensatory measures, the obligation of complying with them is determined by an authority in the course of the proceedings on environmental impact assessment. Any identified noncompliance with the licenses gained will also require solving.

\section{Summary}

Identifying rational variants of achieving the objective, being the target exploitation of natural shale gas, comparing the impacts of the various options for producing natural gas, taking into account various aspects, primarily including the environmental one, result in the special importance of the procedure for environmental impact assessments. Managing the multi-level process of environmental impact assessment will be important in the activities of the Concessionaire in subsequent stages of preparation and the implementation of the investment project. The use of the methods and tools for supporting multi-criteria decisions within the management process of the environmental impact assessment, will help, in a systematic manner, and bind the requirements of strategic documents, the environmental policy and the changing legal regulations of the variants of functional and technical solutions that are feasible in the next stages of the project. It is important to find an approach the problem of gas production in a comprehensive manner, i.e. treat the process as a set of all activities of the Concessionaires and the administration bodies, starting with the search for and identification of deposits, through gas extraction, to the mining plant decommissioning and land reclamation after the end of operations.

Please cite as: Nafta-Gaz 2015, no. 11, pp. 910-916, DOI: 10.18668/NG2015.11.14

Article contributed to the Editor 31.08.2015. Approved for publication 7.10.2015.

The article is result of research conducted in connection with a project: Environmentally friendly and feasible, from the economic point of view, technologies of water, sewage and waste management at the extraction of shale gas, co-funded by the National Centre for Research and Development as part of the programme BLUE GAS - POLISH SHALE GAS. Contract No. BG1/EKOŁUPKI/13. 


\section{Literature}

[1] Kasza P.: Efektywne szczelinowanie lupkow w Polsce. Nafta-Gaz 2013, no. 11, pp. 807-813.

[2] Kasza P.: Zabiegi stymulacji wydobycia $w$ niekonwencjonalnych zlozach weglowodorow. Nafta-Gaz 2011, no. 10, pp. 697-701.

[3] Matyasik I., Sloczynski T.: Niekonwencjonalne zloza gazushale gas. Nafta-Gaz 2010, no. 3, pp. 167-177.

[4] Ocena zasobow wydobywalnych gazu ziemnego i ropy naftowej $w$ formacjach lupkowych dolnego paleozoiku w Polsce (basen baltycko-podlasko-lubelski). Raport pierwszy, PIG - PIB, Warszawa 2012.

[5] Podgajniak T., Behnke M., Szymanski J.: Wybrane aspekty oddziaływań srodowiskowych. EKO-KONSULT, Gdansk 2003.

[6] Poskrobko B.: Zarzadzanie srodowiskiem. Polskie Wydawnictwo Ekonomiczne S.A., Warszawa 2007 (2012).

[7] Risk Management of Shale Gas Developments and Operations, Det Norske Veritas AS, January 2013; https:/www. dnvgl.com/oilgas/natural-gas/unconventional-gas.html (access on: August 2015).

[8] Sheate W., Byron H., Dagg S., Cooper L.: The Relationship between the EIA and SEA Directives. Final Reports to the European Commission, Imperial College London Consultants Ltd. London, 2005; http://ec.europa.eu/environment/ (access on: August 2015).

[9] Zaleska-Bartosz J., Tyszecki A.: Identyfikacja uwarunkowan formalno-proceduralnych. Opracowanie (niepublikowane) w ramach zadania WP1 w projekcie Ekołupki realizowanym w ramach programu Blue Gas - Polski Gaz Łupkowy, 2014.

\section{Legal and normative acts}

[10] Dlugookresowa Strategia Rozwoju Kraju. Polska 2030. Trzecia fala Nowoczesności. Uchwała Nr 16 Rady Ministrów z dnia 5 lutego 2013 r. (M. P. 2013, poz. 121).

[11] Dyrektywa Parlamentu Europejskiego i Rady 2001/42/WE z dnia 27 czerwca 2001 r. w sprawie oceny wpływu niektórych planów i programów na środowisko; http://
eur-lex.europa.eu/legal-content/PL/TXT/?uri=CELEX:32001L0042\&qid=1444055979744 (access on: August 2015).

[12] Dyrektywa Parlamentu Europejskiego i Rady 2014/52/UE z dnia 16 kwietnia 2014 r. zmieniająca Dyrektywę 2011/92/ UE w sprawie oceny wpływu wywieranego przez niektóre przedsięwzięcia publiczne i prywatne na środowisko; http://eur-lex.europa.eu/legal-content/PL/TXT/?uri=CELEX:32014L0052 (access on: August 2015).

[13] Dyrektywa Parlamentu Europejskiego i Rady 94/22/WE z dnia 30 maja 1994 r. w sprawie warunków udzielania i korzystania z zezwoleń na poszukiwanie, badanie i produkcję węglowodorów; http://eur-lex.europa.eu/legal-content/PL/ TXT/?qid=1440421617467\&uri=CELEX:31994L0022 (access on: August 2015).

[14] Krajowa Strategia Rozwoju Regionalnego 2010-2020: Regiony, Miasta, Obszary wiejskie. Uchwała Rady Ministrów z dnia 13 lipca 2010 r. (M. P. 2010 Nr 36, poz. 423).

[15] Polityka energetyczna Polski do 2050 roku - projekt; http:// bip.mg.gov.pl/node/24670 (access on: August 2015).

[16] Strategia Bezpieczeństwa Energetyczne i Środowisko - perspektywa do 2020 roku. Uchwała nr 58 Rady Ministrów z dnia 15 kwietnia 2014 r. (M. P. 2014, poz. 469).

[17] Strategia Rozwoju Kraju 2020. Uchwała Nr 157 Rady Ministrów z dnia 25 września 2012 r. (M. P. 2012, poz. 2012).

[18] Ustawa $z$ dnia 3 października 2008 r. o udostępnianiu informacji o środowisku i jego ochronie, udziale społeczeństwa w ochronie środowiska oraz o ocenach oddziaływania na środowisko (Dz. U. z 2013 r. z późn. zm.).

[19] Zalecenie Komisji Europejskiej z dnia 22 stycznia 2014 r w sprawie podstawowych zasad rozpoznawania i wydobywania węglowodorów (takich jak gaz łupkowy) z zastosowaniem intensywnego szczelinowania hydraulicznego; http://eur-lex. europa.eu/legal-content/PL/TXT/?uri=CELEX:32014H0070 (access on: Agusut 2015).

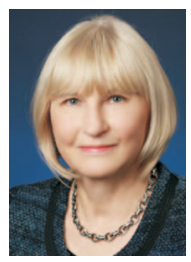

Joanna ZALESKA-BARTOSZ M.Sc. Eng.

Senior Technical Research specialist

Head of the Environmental Assessment Department

Oil and Gas Institute - National Research Institute

ul. Lubicz 25 A

31-503 Kraków

E-mail: zaleska-bartosz@inig.pl

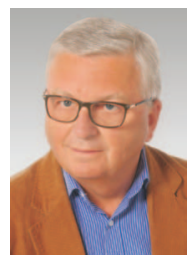

Dr. Eng. Andrzej TYSZECKI PhD.

EKO-KONSULT Design and Consultancy Office

ul. Kościerska 5

80-328 Gdańsk

E-mail: atyszecki@ekokonsult.pl 